\title{
READING SURAH YASIN AT NIGHT: Study of Takhrij al-Hadits
}

\author{
Asrar Mabrur Faza \\ IAIN Zawiyah Cot Kala Langsa \\ asrarmabrurfaza@ymail.com
}

\begin{abstract}
Based on Hadith which is still debatable, we are suggested to read certain Surah in alQur'an, such as reading of Surah Yasin at night, But, it is still needed to re-clarified to see the source or quality. The study of Takhrij hadith is a means to conduct those clarified. Search resources of Hadith code about reading Surah Yasin at night is done by using one of Takhrij methods. Searching the quality of hadith is done by analysis of rijal (criticism of sanad) and analysis of material (criticism of matan). Thus, it can be obtained that hadith of reading surah Yasin is more listed outside al-kutub al-tis'ah, as well as weak, both in the aspect of sanad and matan.
\end{abstract}

Keywords: Takhrij, Criticism, Hadith, and Surah Yasin

\begin{abstract}
Abstrak
Anjuran pembacaan surah tertentu dari al-Qur'an, seperti pembacaan surah Yasin pada malam hari, didasari oleh hadits-hadits yang masih diperdebatkan. Serta masih terbuka untuk ditelusuri ulang baik sumber kodifikasi maupun kualitasnya. Studi Takhrij hadits adalah sarana untuk melakukan kedua penelusuran tersebut. Penelusuran sumber kodifikasi hadits tentang pembacaan Surah Yasin di malam hari dilakukan dengan menggunakan salah satu metode takhrij yang ada. Penelusuran kualitas hadits tersebut dilakukan dengan analisis rijal (kritik sanad) dan analisis material (kritik matan). Sehingga dapat diperoleh hadits tentang membaca surah Yasin lebih banyak tercantum di luar al-kutub al-tis'ah, serta berstatus dhaif, baik pada aspek sanad maupun matan.
\end{abstract}

Kata Kunci: Takhrij, Kritik, Hadits, dan Surah Yasin

\section{Introduction}

In the religion literature (al-kutub aldiniyyah), to attract Muslim reading interest, it is sometimes used in the legitimacy of some of the history which come from Prophet. Legitimacy is not only related to read of al-Qur'an in general, but also related to certain ayat and surah in alQur'an. Muhib al-Din 'Abd al-Subhan Wa'i" in $\mathrm{Fa}$ a il Surah Yasin fi Mizan al-Naqd collected some history about virtues of reading surah Yasin. One of the history is about reading surah Yasin at night. Muhib al-Din assess that Hadith as Hadith mursal, ${ }^{1}$ Because it is considered al-

\footnotetext{
${ }^{1}$ Hadith of mursal can identify through statenebt of senior tabi' in (kibâr al-tâbi 'în) or junior tabiin (Shigâr al-tâbi î̀n) that explain that Prophet SAW did this and that. This report
} 
Hasan is not so much narrated from $\mathrm{Abu}$ Hurayrah. ${ }^{2}$ But how the case about assessment, or how the real status hadith about reading surah Yasin, especially in the study of takhrij method. To know these things need to be undertaken study in more depth in the form of scientific writings. Based on the background of the problem above, focus of study in this paper will formulate in the formulation of the problem: How the Status of Hadith about reading Surah Yasin at Night by Study of Takhrij Hadith?.

\section{Discussion}

\section{Takhrij al-Hadits:: A Trace Methods and Analysis Hadith}

In early development, takhrij hadith interpreted by narration of a narrator (called mukharrij) in his book with its own narrator. ${ }^{3}$ Then on the subsequent development, takhrij Hadith also meant present hadith from various books of origin (read: the source), and then reported back to the arrangement narrator itself coupled with the inclusion of information about the quality of hadith narrated it. But in recent times, takhrij hadith activities also mean efforts to articulate and demonstrate source of the hadith is accompanied by an explanation for its quality. ${ }^{4}$

explain without friends name who got hadith direcly from prophet Muhammad SAW. see Zayn al-Dîn 'Abd al-Rahîm bin al-Husayn al-'Irâqî, Fath al-Mughîts bi Syarh Alfiyah al-Hadîts (Beirut: Dâr al-Fikr, 1995), 63-65; Sâjid alRahmân al-Shiddîqî, al-Mu 'jam al-Hadîth fì 'Ulûm alHadîth (Beirut: Dâr al-Kutub al-'Ilmiyyah, 2005), 112; 'Abd al-Rahmân bin Ibrâhîm al-Khamîs, Mu 'jam 'Ulûm al-Hadîth al-Nabawî (t.t: Dâr Ibn Hazm, t.th.), 207, 208. ${ }^{2}$ Muhib al-Dîn 'Abd al-Subhân Wâ'i“', Faâ'il Sûrah Yâsîn fì Mîzân al-Naqd (Beirut: Mu'assasah al-Rayyân, t.th.), 74. ${ }^{3}$ Takhrîj literally meant bariza min maqarrihi (arising out of place). atau akhraja al-syai' (issuing something). If this term is used to the Hadith, it could mean: Removing the traditions of the place. See al-Shiddîqî, al-Mu jam, 37.

${ }^{4}$ The development of this concept is recognized by Zulfahmi Alwi. See at Zulfahmi Alwi "Metodologi Takhrîj al-Hadîth: Memantapkan Keberadaan Ilmu Takhrîj al-Hadîth sebagai Disiplin Ilmu," Jurnal Tahdis, First Edition, First year
Thus there are two takhrij objectives: First, searches Hadith source (mashdar). Secondly, knowing hadith condition from receiver and deduction. As proposed by Abu Muhammad 'Abd al-Muhdy bin 'Abd al-Qadir bin 'Abd al-Hadi. ${ }^{5}$

There are five hadith search methods that can be used in takhrij hadith. First, searches hadith based on narrator at the level of best friends. Secondly, search hadith based on narrator of the initial wording narrator used. Third, searches hadith by one of words of narrator that is considered rare used. Fourth, search hadith by theme of hadith generally. Fifth, searches hadith by status (quality) sanad or matan hadith. ${ }^{6}$

In line with the analysis of hadith, it can be divided into two, namely: First, Rijal analysis (Critique of Sanad). Second, material analysis (Critique of Matan). In the first part, the method refers to true authentic hadith, formula which must be fulfilled: linkage of sanad, justice of narrators, narrators understanding, no syadz, and no 'illah. These points are the nature of true hadith narrator. ${ }^{7}$ In the second part, it still refer to the last two points that are also part of the true hadith narrator, namely no syadz and 'illah. Both are part of the nature of the true hadith narrator. To prove the existence of these, the author divides the study become two parts analysis (inform of critics): ${ }^{8}$

(Januari-Juni 2010): 11. The formulation of Takhrîj alHadith can be see at Abû Muhammad 'Abd al-Muhdî bin 'Abd al-Qâdir bin 'Abd al-Hâdî, luruq Takhrîj (t.tp.: Dâr al-I’tishâm, 1987), 10; Mahmûd al-lahhân, Ushûl al-Takhrîj wa Dirâsah al-Asânîd, cet. III (Riyad: Maktabah al-Ma'arif li al-Nasyr wa al-Tauzî‘, 1996), 10.

${ }^{5}$ see al-Hâdî, luruq, 11.

${ }^{6}$ In practice, the methods of searches of hadith become a free option for a researcher of hadith. However, for more accurate and maximum search efforts of hadith, can be used as much as possible of the existing methods, in the sense of not only focused on one or two methods alone, as proposed Zulfahmi Alwi, Metodologi, 24.

${ }^{7}$ To formulate true hadith can be see at Abû 'Amrû 'Utsmân bin 'Abd al-Rahmân Al-Syahrazûrî, Ma 'rifah Anwâ' 'Ilm al-Hadits, cet. I (Beirut: Dâr al-Kutub al-'Ilmiyyah, 2002), 79.

${ }^{8}$ See Syuhudi Ismail, Metodologi Penelitian Hadis Nabi, cet.II (Jakarta: Bulan Bintang, 2007), xiii. 
First, redaction criticism, in the form of searching pronunciation difference, knowing there is a difference due pronunciation like its happening "revision" of text in terms ziyadah (additional text), idraj (present the text except hadith) and others. ${ }^{9}$ Second, substantial criticism, in the form of search aspects: ${ }^{10}$ Interpretive relevance of alQur'an, the relevance of recommendation of other authentic narrations, and the relevance of stylish with prophetic expressions. ${ }^{11}$

\section{Study of Takhrij Hadith about Reading Surah Yasin at Night}

Hadith Text about issues above can be seen

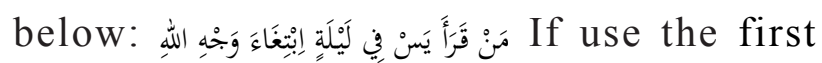
hadith the search method, it certainly cannot be done, because the text is not listed hadith $a$ \% $l a$ of narrator name (friend). If it use one of the search methods from existing hadith, like the second

${ }^{9}$ Here the authors offer some steps can be taken to find a possible "revision" that occurred in matan hadith, namely: (a) looking at the sides of difference (nawâhi al-ikhtilâf) that exist on hadith redaction, (b) search status of (martabah) narrator of different narration, (c) seach two names of narrator from each problematic narrator, (d) analysis cause of problematic from martabah narrator from ke

abiman, (e) do confirm reductional toward rijâl which is more tsiqah and having more quality, and (f) give conclusion by: identification of "renew" content, and form of "revision" have done.

${ }^{10}$ This formula used standard of al-Adlabî. see balâh alDîn bin Ahmad al-Adlabî, Manhaj Naqd al-Matn 'inda 'Ulamâ' al-Hadîts, edt. III (Beirut: Dâr al-Afâq al-Jadîdah, 1983), 238, 329.

${ }^{11}$ Here is an explanation of the term that writer use in three sub criticism substantial hadith above: First, relevance interpretative al-Qur'an hadith intention is to be studied must function as parrots or tafsir (interpretation) of the views contained in al-Qur'an. Second, relevance recomendation of other true narrations point is studied hadith must have relevance to other true hadith which may serve as a reinforcement of the argument (rekomendative). Third, relevance stylish with prophetic phrase means that hadish examined must show a proper expression in part be attributed to the Prophet, with no indication of the presence of randomness diction of word, it does not meant that is low and there are no terms of scientific is known by scholars before. compare the writer description with work of alAdlabî. Lihat al-Adlabî, Manhaj, 238, 329. method, which is based on the first sentence, from matan hadith, the pieces of these hadith can be found in Sunan al-Darimi, it is complete text hadith: ${ }^{12}$

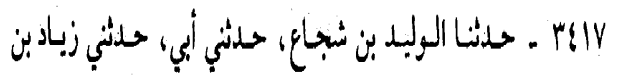

$$
\begin{aligned}
& \text { خبئنة، عز محمد بن جحادة، عز الحسز، عن أبي مربرة، نال: نال }
\end{aligned}
$$

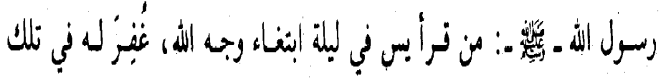

(al-Darimi berkata:) al-Walid bin Syuja ‘ has told us (he said), my father has been delivered to me (he said), Ziyad bin Khaitsamah had delivered to me (he says), from Muhammad bin Juhadah, from al-Hasan, dari Abu Hurayrah, he said: The Messenger SAW has said: "Whoever reads (surah) yasin at night, because search for (the pleasure of) Allah, (so his sin) will be forgiven on that night."

To simplify the next analysis, it will be displayed Sanad scheme, narrator hadith special will be assessed is Sunan al-Darimi: 


\section{SKFML SANADHADIS TENTANG MEHBACA SLRAH YASTY DI MALAM HARI RTWAYAT ALDARDII}

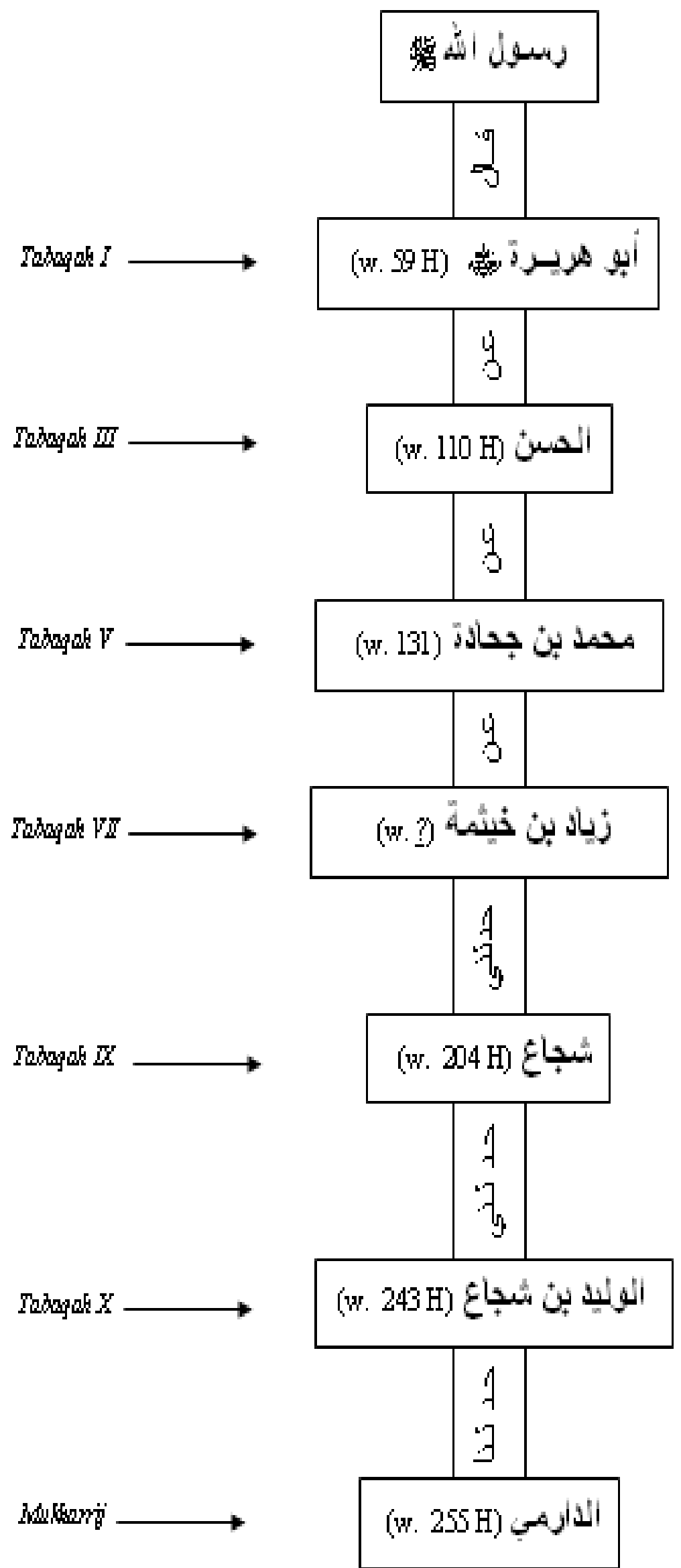




\section{Analysis of Hadith about reading Surah Yasin} at Night

1) Analysis of Rijal (Critique of sanad)

The complite name of Abu Hurayrah is 'Umair bin 'Amir bin 'Abd bin al-Sarri bin larif bin 'Attab bin Abi Sha'b bin Munyah bin Sa'd bin Tsa'labah bin Fahm bin Ganam bin Daus bin Abdillah bin Zahran bin Ka'ab bin al-Harits Ibn 'Abdilllah bin Malik bin Nashr al-Azdi. But familiar name is 'Abd al-Rahman bin Sakhr Abu Hurayrah al-Dausi al-Yamani. He died in $59 \mathrm{H}$ at the age of 78 years. Abu Hurayrah is a Companion of the Prophet SAW, the jobless or unemployment, and he was often in the mosque when he felt hungry Abu Hurayrah life with Prophet s aw. For 3 or 4 years, there are many narrated from him, beside other companions (such as Abu Bakr, 'Umar, Ubay bin $\mathrm{Ka}$ 'ab, and others). ${ }^{13}$ However, based on existing historical records, Abu Hurayrah had "abnormalities" in the form of neurological disorders, which suffered from epilepsy (seizures) if he experienced hunger. Until people believe it had lost of mind. In some histories said that sustenance of Abu Hurayrah came from helping hands of others. ${ }^{14} \mathrm{Abu}$

\footnotetext{
${ }^{13}$ Abû Hurayrah always actively highlighting the activities of Prophet. It is said that Abû Hurayrah often entered into prophet house, attending meetings with the Prophet, even been with the Prophet. However, there is one time Abû Hurayrah was not with Prophet SAW, it was whent the Prophet sent Abû Hurayrah bersama al-'Alâ' al-Hadramî to Bahrayn on 8 H. see iyâ' Muhammad Mahmûd Jâsim, Daur al-Shahâbah fi Hif" al-Sunnah al-Nabawiyah wa Nasyrihâ, cet. I (Beirut: Dâr al-Kutub al-'Ilmiyyah, 2007), 57.

${ }^{14}$ Syams al-Dîn Muhammad bin Ahmad bin 'Utsmân alDzahabî, Siyar A 'lâm al-Nubalâ', juz II, edt. II (Beirut: Mu'assasah al-Risâlah, 1982), 578-589. 578-595; Abû alFal Ahmad bin 'Alî bin Hajar Syihâb al-Dîn al-'Asqalânî al-Syâfi'‘̂ (next written by al-'Asqalânî), Tahdzîb alTahdzîb, juz IV (t.tp: Mu'assasah al-Risâlah, t.th.), 601602; Abû al-Fal Muhammad bin lâhir bin 'Alî al-Maqdisî, Kitâb li Jam ' bayna Kitâbay Abî Nashr al-Kalâbâdzî wa Abî Bakr al-Ashfihânî, juz II, cet. II (Beirut: Dâr al-Kutub al-'Ilmiyyah, 1405 H), 600-601; Abû al-Husayn 'Abd alBâqî bin Qâni‘, Mu'jam al-Shahâbah, juz II (t.tp.: Maktabah al-Gurabâ' al-Atsariyyah, t.th.), 194; Syams al-
}

Hurayrah apparently did not practice some Prophet Hadith. of his own narrated, namely as:

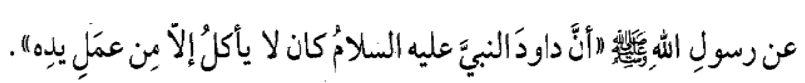

(From the Prophet: "Surely (the Prophet) Daud AS. Do not eat unless of (results) in his own right)". ${ }^{15}$ Thus, Abu Hurayrah could belong to the person who gets exhortation from al-Qur'an, namely: It is most hateful in the sight of Allah that you say what you did not do (Surat al-Shaff (61): 3).

Al-Hasan, known by the name al-Hasan bin Abi al-Hasan (Yassar) al-Bashri, kuniyah-nya Abu Sa'id. Al-Hasan is descendant (maula) Zaid bin Tsabit Ra., another says descendants of Jabir bin Abdillah ra. Al-Hasan was born in Medina $21 \mathrm{H}$, in the past khilafah 'Umar bin al-Khattab (approximately two years before the death of the caliph). Al-Hasan died at the age of 88/ 89 years, precisely on Friday night of Rajab $110 \mathrm{H}$, al-Hasan narrated some hadith of some companions of the Prophet SAW, they are: Ubay bin $\mathrm{Ka}^{\text {'ab }}$, Abu Bakrah, 'Ammar bin Yasir, 'Umar bin al-Khammab, Abu Hurayrah and others. AlHasan also took hadith from tabi in, such as: alAhnaf bin Qays, and others. Among his students was: Muhammad bin Juhadah, Qatadah, and others. According to Ibn Hajar: Tsiqah faqih fail masyhur. Information of al-Bazzar mention that if al-Hasan narrated from a group of people or from people who have never met, using the word haddatsana wa akhbarana, which is derived from the people who never convey hadith and deliver a preach in Basra.

Specifically related to narration of al-Hasan from Abu Hurayrah, Abu Hatim al-Razi commented that it is not correct information about al-Hasan narrated hadith from Abu Hurayrah. Husyaim cites the opinion of Ibn 'Awn that al-

\footnotetext{
${ }^{15}$ see Abû 'Abdillâh Muhammad bin Ismâ‘îl al-Bukhârî, Shahîh al-Bukhârî, edt. I (Damaskus: Dâr Ibn Katsîr, 2002), 499.
} 
Hasan narrated literal meaning. Bahz bin Asad said that al-Hasan did not get hadith of Abu Hurayrah, moreover, he never even saw Abu Hurayrah. He added that al-Hasan narrated hadith by Samurah book. Yunus bin 'Ubayd also said that al-Hasan never see Abu Hurayrah. This comments (did not see Abu Hurayrah) stated by Ibn al-Madini, Abu Hatim, al-Bazzar, and Abu Zur'ah. According Abu Zur'ah who said haddatsana Abu Hurayrah. So, narrator was yukhmi'(did mistake). ${ }^{16}$ Abu Hatim said that in fact al-Hasan never narrated a hadith of $\mathrm{Abu}$ Hurayrah. ${ }^{17}$ But the information about al-Hasan has said that he never narrated a hadith about khulu' from Abu Hurayrah. However, this is disputed by al-Nasa'i. ${ }^{18}$

Ibn Sirin had a problem with Al-Hasan. So that Ibn Sirin was not "air-sympathy" at the time of the death of al-Hasan. This is due to previous al-Hasan which trifled with Ibn Sirin, until he

\footnotetext{
${ }^{16}$ see 'Uwaidah, al-Hasan al-Bashrî: Imâm Ahl al-Bashrah, edt. I (Beirut: Dâr al-Kutub al-'Ilmiyyah, 1995), 67; Abû al-Fal Ahmad bin 'Alî bin Hajar Syihâb al-Dîn al- 'Asqalânî al-Syâfi'î (then writen by al-'Asqalânî), Tahdzîb al-Tahdzîb, juz I (t.tp: Mu'assasah al-Risâlah, t.th.), 391.

${ }^{17}$ see Jamâl al-Dîn Abû al-Hajjâj Yûsuf al-Mizzî, Tahdzîb al-Kamâl fî̀ Asmâ' al-Rijâl, juz VI, cet. I (Beirut: Mu'assasah al-Risâlah, 1983), 95-127; 'Abd al-Gaffâr Sulaymân al-Bandârî dan Sayyid Kisruwai Hasan, Mausû'ah Rijâl Kutub al-Tis 'ah, juz I, cet. I (Beirut: Dâr al-Kutub al-'Ilmiyyah, 1993), 322; Syihâb al-Dîn Ahmad bin 'Alî bin Hajar al-'Asqalânî al-Syâfi'î (then writen by al-'Asqalânî), Taqrîb al-Tahdzîb, edt. III (Damaskus: Dâr al-Qalâm, 1991), 160; Abû al-Mahâsin Muhammad bin 'Alî al-'Alawî al-Husayni, Kitâb al-Tadzkîrah li Ma'rifah Rijâl al-Kutub al-'Asyrah, juz I (Kairo: Maktabah al-Khânijî, t.th.), 318; see 'Abd al-Rahman Ra'fat al-Bâsyâ, Shuwar min Hayâh al-Tâbi 'în (t.tp.: Dâr al-Adab al-Islâmî, 1997), 98, 107; Abû Muhammad 'Abd al-Rahmân bin Abî Hâtim Muhammad bin Idrîs al-Tamîmî al-Han"alî al-Râzî, al-Jarh wa al-Ta 'dîl, juz III, cet. I (Beirut: Dâr al-Kutub al'Ilmiyyah, 2002), 46, 47; Al-'Asqalânî, Tahdzîb, juz I, 388390; Shalâh al-Dîn Khalîl bin Îbik al-Shafdî, al-Wâfî bi alWafâyât, juz XII, cet. I (Beirut: Dâr Ihyâ' al-Turâts al'Arabî, 2000), 190-191. 'Uwaydah, al-Hasan, 66, 67, 69. ${ }^{18}$ See Abû 'Abd al-Rahman Ahmad bin Syu'aib Ibn 'Alî al-Nasâ'̂̂, al-Mujtabâ min al-Sunan al-Masyhûr bi alSunan al-Nasâ' '̂ (Riyad: Bayt al-Afkâr al-Dawliyah, t.th.), 365 .
}

said: "would not mention the name of the weaver in front of us da 'una min dzikr al-hakah)"'19

According to the authors, one of the problems which occurred between Ibn Sirin and al-Hasan is about hadith narration. This can be evidenced by the same with the hadith discussed before, namely through Ibn Sirin from Abu Hurayrah. ${ }^{20}$ Thus a conflict emerged when Ibn Sirin was unsatisfied with the way al-Hasan narration. The way of this narration was as admitted by Ibn Sirin by saying that al-Hasan after listening to hadith, he then "renew" the pronunciation and convey words of a lesson. ${ }^{21}$

According to al-Dzahabi, al-Hasan is tsiqah narrator, but do tadlis from Abu Hurayrah, ${ }^{22}$ and also from others. Al-Hasan including a narrator who did a lot irsal and tadlis, that according to Ibn Hajar al-'Asqalani. ${ }^{23}$ 'Awwad al-Khalaf in his dissertation (published) cites the opinion of alDzahabi, which says:

Al-Hasan al-Bashri did a lot of tadlis, If he said in his hadith: 'An fulan, (so) weak of hujjah, especially for those who are considered never heard such as Abu Hurayrah and others. Therefore, they (the scholars) considered that

${ }^{19}$ See al-Shafdî, al-Wâfî, juz XII, 191. 'Uwaydah, al-Hasan, 59.

${ }^{20}$ See Al-Shafdî, al-Wâfî, juz III, 122.

${ }^{21}$ Al-Shafdî, al-Wâfî, juz III, 122. 'Uwaydah, al-Hasan, 26,58 .

${ }^{22}$ Hadith mudallas is generally devided three categories, tadlîs al-isnâd, tadlîs al-suyukh and tadlîs al-taswiyah. The first category means: Hadith narrated by a narrator who says it has received a hadith from a narrator who never met, but actually does not happen narration hadith. The second category means: Hadith narrated by a narrator mention the identity of his teacher (syaikh) (such as: Name, kuniyah, name of country, etc) unfamiliar in the community. This was done intentionally or unintentionally. The third category, purpose: Hadith narrated by a narrator who hide/ no mention of a narrator who "troubled" that is located between the two narrator tsiqah. So by hiding it, as if the narrator narrates from lanes tsiqah only. Narrator who narrated hadith mudallas is called mudallis, while, his activity is called tadlîs. see Al-Shiddîqî, al-Mu 'jam, 100, 110. Compare with al-Khamîs, Mu ‘jam, 68,69. 
hadith was disconnected (munqami $\left.{ }^{\circ}\right){ }^{24}$

Muhammad bin Juhadah, his compilte name is Muhammad bin Juhadah al-Awdi, or al-Iyami al-Kufi. He died in 130/131 H. Among his teachers was: Al-Hasan al-Bashri, 'Ama' bin Abi Rabbah, and others. ${ }^{25}$ Among his students Ziyad bin Khaitsamah, Syu'bah, and others. According to Ibn Hajar: Tsiqah. Abu Dawud and Ahmad bin Hanbal did tautsiq to Muhammad bin Juhadah. Ibn al-Madini: He had (ever) accused of being a follower (organization) Qadariyah. Yahya bin Ma'in: Tsiqah. Al-'Ijli and 'Utsman bin Abi Syaybah: Tsiqah. 'Utsman also added: La ba'sa bihi. Ya'qub bin Sufyan: One Kufa person which is tsiqah. Al-Dzahabi: one of tabiin tsiqah. Abu 'Awanah al-Waah: Kana yaglu fi tasyayyu' (He extreme Syi'ah). This Abu 'Awanah opinion was disputed by al-Dzahabi, because in fact, Muhammad bin Juhadah was proved never narrated hadith containing reproach, as it becomes a tendency sect adherents belonging to its other extreme. ${ }^{26}$

Ziyad bin Khaitsamah, his full nama is Ziyad

\footnotetext{
${ }^{23}$ see Abû 'Abd al-Rahman Ahmad bin Syu'aib bin 'Alî alNasâ'î, Tasmiyah Masâyikh wa Dzikr al-Mudallisîn, edt. I (Mekah al-Mukarramah: Dâr 'Âlam al-Fawâ'id, 1423 H), 121; Sabm Ibn al-'Ajamî al-Syâfi' 'î, Al-Tabyîn li Asmâ'alMudallisîn (Beirut: Dâr al-Kutub al-'Ilmiyah, 1986), 20; Syams al-Dîn Muhammad bin Ahmad al-Dzahabî, Mîzân al-I'tidâl fỉ Naqd al-Rijâl, juz II, cet. I (Beirut: Dâr alKutub al-'Ilmiyyah, 1995), 230; 'Awwâd al-Khalaf, Riwâyât al-Mudallisîn fy Shahîh al-Bukhârî: Jam 'uhâ Takhrîjuhâ al-Kalâm 'alaihâ (t.tp: Dâr al-Basyâ'ir alIslâmiyyah, t.th.), 144.

${ }^{24}$ Al-Khalaf, Riwâyât, 144.

${ }^{25}$ According to Abû Na'îm, There are some tabiin got hadith - about reading surah Yâsîn - it is from al-Hasan, namely, like Yûnus bin 'Ubayd, Muhammad bin Juhâdah and others. see Abû Na'îm Ahmad bin Abdillâh al-Ashfahânî, Hilyah al-Auliyâ' wa labaqât al-Ashfiyâ', juz II, edt. I (Beirut: Dâr al-Kutub al-'Ilmiyyah, 1988), 159.

${ }^{26}$ see Al-Bandârî and Hasan, Mausû 'ah, juz III, 337. Al'Asqalânî, Taqrîb, 471; Syams al-Dîn bin 'Abdilllâh Muhammad bin Ahmad bin 'Utsmân bin Qaymâdz (next written al-Dzahabî), Tadzhîb Tahdzîb al-Kamâl fî Asmâ' al-Rijâl, juz VIII, cet. I (Cairo: al-Fârûq al-Hadîtsiyyah li al-labâ'ah wa al-Nasyr, 2004), 62; Al-Husainî, Kitâb alTadzkîrah, juz III, 1487. Al-Râzî, al-Jarh, juz VII, 299.
}

bin Khaitsamah al-Ju'afi al-Kufi. Ziyad have some teachers, such as: Muhammad bin Juhadah, al-Aswad bin Sa'id and others. Among Ziyad students are: Syuja' bin al-Walyi, Zuhayr bin $\mathrm{Mu}$ 'awiyah and others. According to Ibn Hajar: Tsiqah. Abu Zur'ah: Kufi tsiqah. Yahya bin Ma'in: La ba'sa bihi, on the other hand, said: Ziyad bin Khaitsamah tsiqah. Abu Abdillah bin Khalfun include the name Ziyad in his book, alTsiqat. ${ }^{27}$ Abu Hatim al-Razy: Shalih al-Hadits. ${ }^{28}$ Syuja'(Ayah al-Walid), his full name is Syuja‘ bin al-Walid bin Qays al-Sakuni, kuniyahnya Abu Badr al-Kufi. Syuja' pass away in Ramadan month at 203/204/205. Syuja' got hadith from: Ziyad bin Khaitsamah, al-A'masy, and others. Among his students: Abu Hammam al-Walid bin Syuja' (his own son), Ahmad bin Hanbal dan others. According to al-Dzahabi: AlMuhaddits al-Shalih. Al-Tsawri: in Kufa (this), there are people who are more obedient ( $a^{\prime} b a d$ ) than Syuja' bin al-Walid. Abu Hatim: Laisa bi al-matin, la yuhtajju bi haditsihi. The other Abu Hatim expression is Syuja' a layyin alhadits, except (if) narrated from Muhammad bin 'Amru bin 'Alqamah, (then) hadith is true. Ahmad

Al-‘Asqalânî, Tahdzîb, juz III, 529-530; Al-Mizzî, Tahdzîb, juz XXIV, 575-579; Al-Dzahabî, Mîzân, juz VI, 89, 90; Al-Shafdî, al-Wâfî, juz II, 211.

${ }^{27}$ see Al-Bandârî and Hasan, Mausû' 'ah, juz I, 533. Al'Asqalânî, Taqrîb, 219; Al-Dzahabî, Tadzhîb, juz III, 314; Al-Husainy, Kitâb al-Tadzkîrah, juz I, 525; Abû Hâtim Muhammad bin Hibbân bin Ahmad al-Tamîmî al-Bustî, Kitâb al-Tsiqât, juz VI, edt. I (Hyderabad: Mamba'ah Majlis Dâ'irah al-Ma'ârif al-'Utsmâniyyah, 1978), 319; 'Alâ' al-Dîn Mughlamî Ibn Qalîj bin 'Abdillâh al-Bakjarî al-Hanafî (selanjutnya ditulis al-Bakjarî) Ikmâl Tahdzîb alKamâl fí Asmâ' al-Rijâl, juz V, edt. I (Kairo: al-Fârûq alHadîtsiyyah li al-laba 'ah wa al-Nasyr, 2001), 104; Al-Râzî, al-Jarh, juz III, 479; Al-‘Asqalânî, Tahdzîb, juz I, 645; AlMizzî, Tahdzîb, juz IX, 457-458.

${ }^{28}$ Statement: Shâlih al-hadîts is part of tajrîh pronunciation according to Abû Hâtim al-Râzî, but according to jumhur is part of ta'dîl. According to Abû Hâtim al-Râzî, this statement meant hasan al-hadits (hasan hadith) that is hadiscan be written to $i$ 'tibâr and syawâhid, But It cant be hujjah. see Muhammad Nâshir al-Dîn al-Albânî, al-Rau al-Dânî fí al-Fawâ'id al-Hadîtsiyyah, edt. I (Yordan: alMaktabah al-Islâmiyyah, 1422 H), 64. 
bin Abi Khaitsamah and 'Abd al-Khaliq bin Manshur: Syuja' bin al-Walid tsiqah. Ibn Hajar: Shaduq wara ' lahu awham. Abu Zur'ah al-Razi: La ba'sa bihi. Al-Albani: Tsiqah, it is known in Tahdzib book. The others al-Albani argue: He became the talk (critics), but had no effect (toward credibility). Ahmad: I hope he is shaduq. Ibn Sa'd: He (Syuja') has many (kana katsir alhadits). Abu Zur'ah: La ba 'sa bihi. Ibn Numayr: He (Syuja') tsiqah. ${ }^{29}$ Yahya bin Ma'in: Abu Badr Syuja' bin al-Walid tsiqah. But at the end of the age worth Syuja', there is a problem with Yahya bin Ma'in. ${ }^{30}$

Al-Walid bin Syuja', his full name is alWalid bin Syuja' bin al-Walid bin Qays al-Sakuni al-Kindi al-Kufi, kuniyah-nya Abu Hammam bin Abi Badr al-Kufi. Al-Walid had ever lived (nazil) in Baghdad. Al-Walid pass away on Wednesday 13 Rabiul Awwal 243H in Baghdad. Among his teachers were: Syuja' bin al-Walid (his father), Isma'il bin 'Ayyasy and others. As ever took hadith from al-Walid, They are: Abu Badr (his father), al-Darimi, Abu Dawud, Muslim, and others. According Ibn Hajar: Tsiqah. Ibn Ma'in:

\footnotetext{
${ }^{29}$ see al-Bandârî dan Hasan, Mausû'ah, juz II, 140; Al'Asqalânî, Taqrîb, 264. Al-Dzahabî, Tadzhîb, juz IV, 255; Al-Husainî, Kitâb al-Tadzkîrah, juz II, 695; Al-Râzî, alJarh, juz IV, 343-344; Ahmad Ismâ‘îl Syakûkânî and Shâlih 'Utsmân al-Lahhâm, Mu 'jam Asâmî al-Ruwât alladzîna tarajama lahum al-'Allâmah Muhammad Nâshir al-Dîn al-Albânî Jarhan wa Ta 'dîlan, juz II, edt. I (Beirut: Dâr Ibn Hazm, 2000), 280; Al-Mizzî, Tahdzîb, juz XII, 382388; Al-Dzahabî, Mîzân, juz III, 364; Al-Shafdî, al-Wâfî, juz XVI, 68.

${ }^{30}$ It can bee seen from history told by Ahmad bin Hanbal, cited by al-'Asqalânî in this Tahdzîb al-Tahdzîb: "Last, when along with Yahyâ bin Ma'în, he (Ibn Ma'în) met Abû Badr (Syujâ‘). Ibn said to Abû Badr: Fear Allah !, try to see these Hadith, thy (own) will not narrated to you!Abû 'Abdillâh (Ahmad) said: "I embarrassed, then turned away. "In another story is told well (by Ibn Hanbal):" One day Ibn Ma'în met Abû Badr elderly, said: "Hai braggart (kadzdzâb)!." answerd by Abû Badr: "That if it is true, but if not, may God open your disgrace (fa hattakallahu)." Ahmad said: I though Abû Badr praying happen with Ibn Ma'în.” see al-“Asqalânî, Tahdzîb, juz II, 154; see Al-Mizzî, Tahdzîb, juz XII, 385, 386; Al-Dzahabî, Mîzân, juz III, 365 .
}

La ba'sa bihi, he is not classified as people who never lied. ${ }^{31}$ Shalih Jazrah: Takallamu fihi. Abu Hatim: Syaikh Shaduq, Shaduq la yuhtajju bihi. The other statement of Abu Hatim is: Yuktabu haditsuhu wa la yuhtajju. Al-Nasa'i: La ba'sa bihi. Ibn Hibban put al-Walid name in al-Tsiqat. Musallamah bin Qasim, al-'Ijli dan Abu 'Ali alJayani: La ba'sa bihi. Al-'Ijli also said: I saw him is not good taking hadith. Ahmad bin Hanbal: Uktubu 'anhu (write hadith from him). ${ }^{32}$

Al-Darimi,his complite name is 'Abdullah bin 'Abd al-Rahman bin al-Fal bin Bahram bin 'Abd al-Shamad al-Tamimi al-Darimi alSamarqandi, kuniyah of Abu Muhammad. Based on the narrative of al-Darimi himself, he was born when Ibn al-Mubarak pass away, it is $181 \mathrm{H}$. AlDarimi pass away in $255 \mathrm{H}$ on $74 / 75$ years old and was buried on Friday coincide on 'Arafah day, according to information of Ahmad bin Sayyar. Al-Darimi is compilers Sunan book. Among his teachers were: al-Walid bin Syuja, Yazid bin Harun and others. There also are getting hadith al-Darimi, seperti: Muslim, Abu Dawud, Abu Zur'ah, 'Isa bin 'Umar al-Samarqandi and others. When Ahmad bin Hanbal had once asked about comparing himself with 'Abdullah bin 'Abd al-Rahman (al-Darimi), so Ahmad answered in order him (al-Darimi) is enough to be a reference. Abu Hatim al-Razi: a priest in his time. Bandar aligns al-Darimi name with alBukhari. According to Ibn Hajar: Tsiqah fail mutqin. Ahmad bin Sayyar: Excellent, constituent book al-Musnad and al-tafsir. Raja' bin Murajja: I do not know anyone know more about Hadith than him. Hakim (Abu 'Abdillah): He was

\footnotetext{
${ }^{31}$ Statement Ibn Ma'în: Lâ ba'sa bihi dimaknai tsiqah. see 'Abd al-Mahdî bin 'Abd al-Qâdir bin 'Abd al-Hâdî, 'Ilm al-Jarh wa al-Ta'dîl: Qawâ 'iduhu wa A'immatuhu, edt. II (t.tp.: t.p; 1998), 1998.

${ }^{32}$ see al-Bandârî and Hasan, Mausû' 'ah, juz IV, 176. Al'Asqalânî, Taqrîb, 582; Al-Dzahabî, Tadzhîb, juz IX, 366368. Al-Husaynî, Kitâb al-Tadzkirah, juz III, 1842; Al-Râzî, al-Jarh, juz IX, 10; Al-'Asqalânî, Tahdzîb, juz IV, 317; Al-Mizzî, Tahdzîb, juz XXXI, 22-28; Al-Dzahabî, Mîzân, juz VII, 132; Al-Shafdî, al-Wâfî, juz XXVII, 267.
} 
classified as hafi" hadith "Outstanding". ${ }^{33}$

2) Analysis of Materials (Critique of Matan)

a. Criticism of Redaction

As already noted, that to perform editorial criticism is a form of search the pronunciation differences, and as well as the causes of these differences - in investigating the possibility of whether there is going "revision" of the text of hadith. However, before reviewing it, it will be shown some of hadith texts obtained from search results hadith has ever done before.

Narrated of al-Darimi:

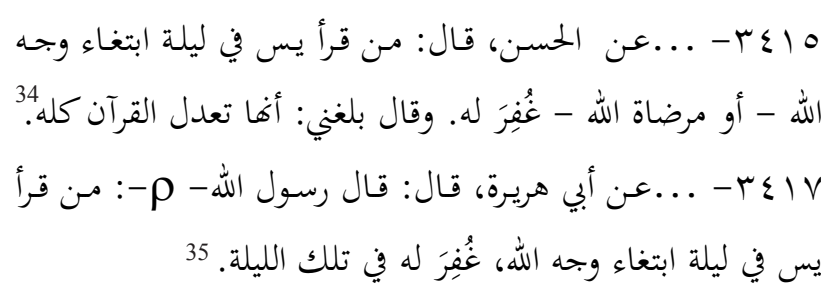

Narrated of Ibn Hibban:

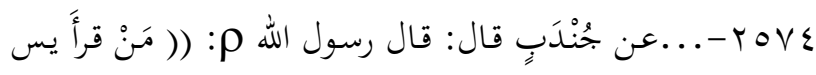

$$
\begin{aligned}
& \text { في ليلة ابتِغَاءَ وَجْهِه اللهِهِفْرَ لَهُ ()). }
\end{aligned}
$$

${ }^{33}$ see Al-Bandârî dan Hasan, Mausû 'ah, juz II, 305; Al'Asqalânî, Taqrîb, 311; Al-Dzahabî, Tadzhîb, juz V, 206208; Al-‘Asqalânî, Tahdzîb, juz II, 373-374; Al-Mizzî, Tahdzîb, juz XV, 210-217.

${ }^{34}$ Al-Dârimî, Sunan Al-Dârimî, juz II, 548. see Jalâl alDîn al-Suyûmî, al-Durr al-Mantsûr fî Tafsîr al-Ma 'tsûr, juz XII, edt. I (Kairo: t.p., 2003), 311.

${ }^{35}$ Al-Dârimî, Sunan Al-Dârimî , juz II, 548.

${ }^{36}$ Al-Amîr 'Alâ' al-Dîn 'Alî bin Balbân al-Fârisî, Shahîh Ibn Hibbân bi Tartîb Ibn Balbân, juz VI, edt. II (Beirut: Mu'assasah al-Risâlah, 1993), 312; see Abû al-Fal Zayn al-Dîn 'Abd al-Rahîm bin al-Husayn al-'Irâqî, al-Mugnî 'an Haml al-Asfâr fî Takhrîj mâ fî al-Ihyâ' min al-Akhbâr, juz I, edt. I (Riyad: Maktabah labariyyah, 1995), 321; 'Imâd al-Dîn Abû al-Fidâ' Ismâ‘̂̂l bin Katsîr al-Dimasqî (then writen by Ibn Katsîr), Tafsîr al-Qur'ân al- 'A “îm, juz XI, edt. I (Jezah: Mu'assasah Qurmubah, 2000), 343; at Syihâb al-Dîn Ahmad bin Abî Bakr bin Ismâ‘îl al-Bûshîrî, Ithaf alKhîrah al-Maharah bi Zawâ'id al-Masânîd al- 'Asyrah, juz VI, edt. I (Riyad: Dâr al-Waman li al-Nasyr, 1999), 259; Nûr al-Dîn 'Alî bin Abî Bakr al-Haytsamî, Mawârid al'am'ân ilâ Zawâid Ibn Hibbân, juz II, edt. I (Damaskus: Dâr al-Tsaqâfah al-'Arabiyyah, 1990), 408.
Narrated of al-Bayhaqi:

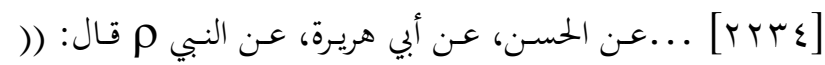

$$
\begin{aligned}
& \text { مَن قرأ يَس كلّ ليلة غُفِر له (). }
\end{aligned}
$$

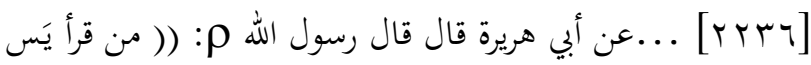

$$
\begin{aligned}
& \text { في ليلة ابتغاء وجه الله غُفر له تلك الليلة )). }
\end{aligned}
$$

Narrated of al-labrani:

$$
\begin{aligned}
& \text { و . هـ- ...عن أَبي هُرَيرةَ قَالَ: قَالَ رَسُولُ الله م: (( مَنْ قَرَأ }
\end{aligned}
$$

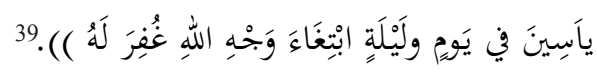

Narrated of Abu Dawud al-layalisi:

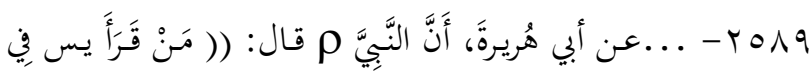

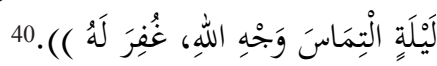

Narrated of Abu Ya'la Mawshili:

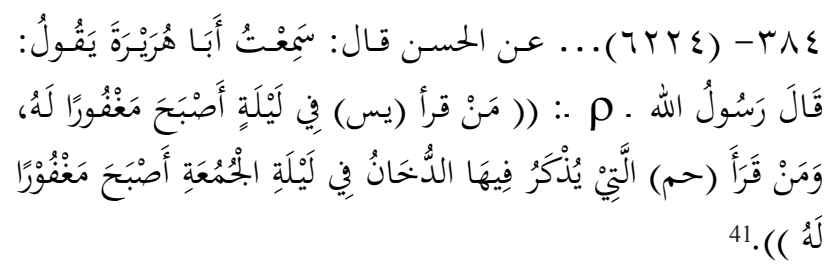

Narrated of Ibn al-Sinni:

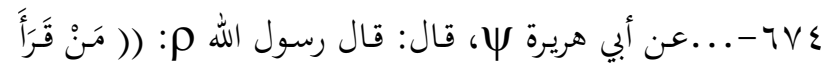

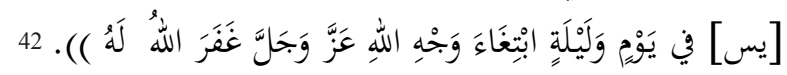

${ }^{37}$ Abû Bakr Ahmad bin al-Husayn al-Bayhaqî, al-Jâmi ‘ $l i$ Syu'ab al-Îmân, juz IV, edt. I (Riyad: Maktabah al-Rusyd, 2003), 95;see al-Suyûmî, al-Jâmi`, juz II, 538; Muhammad Nâshir al-Dîn al-Albânî, a îf al-Jâmi “ al-Shagîr wa Ziyâdatuhu: Al-Fath al-Kabîr, edt. III (Beirut: Maktab al-Islâmî, 1988), 835.

${ }^{38} \mathrm{Al}$-Bayhaqî, al-Jâmi‘, juz IV, 96.

${ }^{39}$ Abû al-Qâsim Sulaymân bin Ahmad al-labrânî, al-Mu ‘jam al-Awsam, juz IV (Cairo: Dâr al-Haramayn, 1995), 21.

${ }^{40} \mathrm{Ibn}$ al-Jârûd, Musnad, juz IV, 212.

${ }^{41}$ Ahmad bin 'Alî bin al-Mutsannâ al-Tamîmî, Musnad Abî Ya 'lâ al-Mawshilî, juz XI, cet. II (Damaskus: Dâr al-Ma'mûn li Turâts, 1989), 94; see Ahmad bin 'Alî bin Hajar al-'Asqalânî, alMamâlib al- 'Aliyyah bi Zawâid al-Masânîd al-Tsamâniyyah, juz XV, cet. I (t.tp.: Dâr al-'Âshimah, 1998), 130; Ibn Katsîr, Tafsîr, juz XI, 342. see al-Bûshîrî, Ithaf, juz VI, 259.

${ }^{42}$ Abû Bakr Ahmad bin Muhammad al-Dînaurî, know as Ibn al-Sinnî, Kitâb 'Amal al-Yawm wa al-Laylah, edt. I 
Narrated of Ibn 'Adi:

$$
\begin{aligned}
& \text {...عن أنس قال رسول الله م: (( من قرأ يس في كل ليلةٍ ابتغاء } \\
& \text { وَجْْهِ الله عزَّ وجلَّ غفر له )( ). }
\end{aligned}
$$

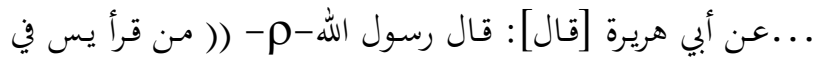

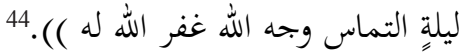

Narrated of Ibn al-Jauzi:

(

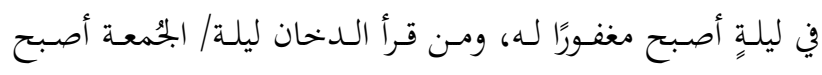

$$
\text { مغفورا له (). من اصنح }
$$

Narrated of Ibn Sammak:

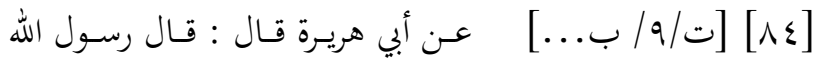

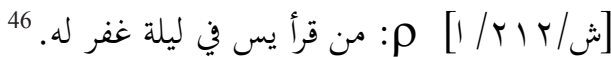

Narrated of Ibn Muqri':

$$
\begin{aligned}
& \text {...عن أبي هريرة عن النبي م قال: (( من قرأ يس في ليلة التماس } \\
& \text { وجه الله (عز وجل) غفر له )). }
\end{aligned}
$$

Narrated of Abu Naym:

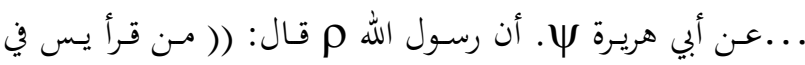

$$
\begin{aligned}
& \text { ليلة التماس وجه الله غفر له )). }
\end{aligned}
$$

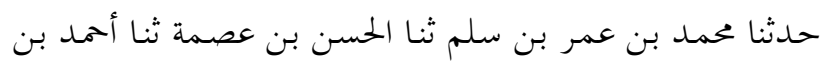

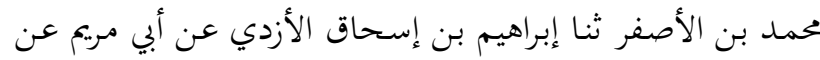

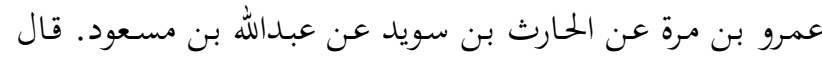
قال رسول الله م قال: (( من قرأ يس في ليلة أصبح مغفورا له. $49 \cdot(($
(Damaskus: Maktabah Dâr al-Bayân, 1987), 318; see alBûshîrî, Ithaf, juz VI, 259.

${ }^{43}$ Abû Ahmad 'Abdullâh bin 'Adî al-Jurjânî, al-Kâmil fíu 'afầ ' al-Rijâl, juz VI (Beirut: Dâr al-Kutub al-'Ilmiyyah, t.th.), 329. ${ }^{44} \mathrm{Al}$-Jurjânî, al-Kâmil, juz III, 121, 122.

${ }^{45} \mathrm{Abû}$ al-Farj 'Abd al-Rahmân bin 'Alî bin Muhammad bin Ja'far Ibn al-Jawzî, Kitâb al-Mau

û 'ât min al-Ahâdîts al-Marfû 'ât, juz I, edt. I (Riyad: Adwâ' al-Salaf, 1997), 402, 403.

${ }^{46}$ Ibn al-Sammâk, Juz' Hanbal: al-Tâsi ' min Fawâ 'id Ibn al-Sammâk, tahqiq by Hisyâm bin Muhammad, edt. I (Riyad: Maktabah al-Rusyd, 1998), 119.
${ }^{47}$ Ibn Muqri', al-Mu 'jam, edt. I (Riyad: Maktabah al-Rusyd, 1998), 53.

${ }^{48}$ Al-Ashfahânî, Hilyah, juz II, 159.

${ }^{49}$ Ibid., juz IV, 130. 
SKEMA WARLASI BEHTUK MATAH

\section{HADIS TEHTAHE MEMTACA SUAAH YASTH DI MALAM HAHI}

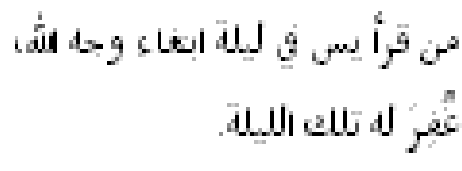

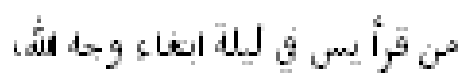

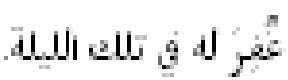

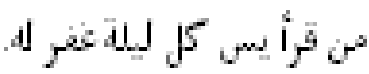

LAL

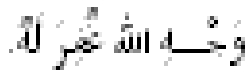

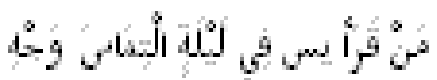

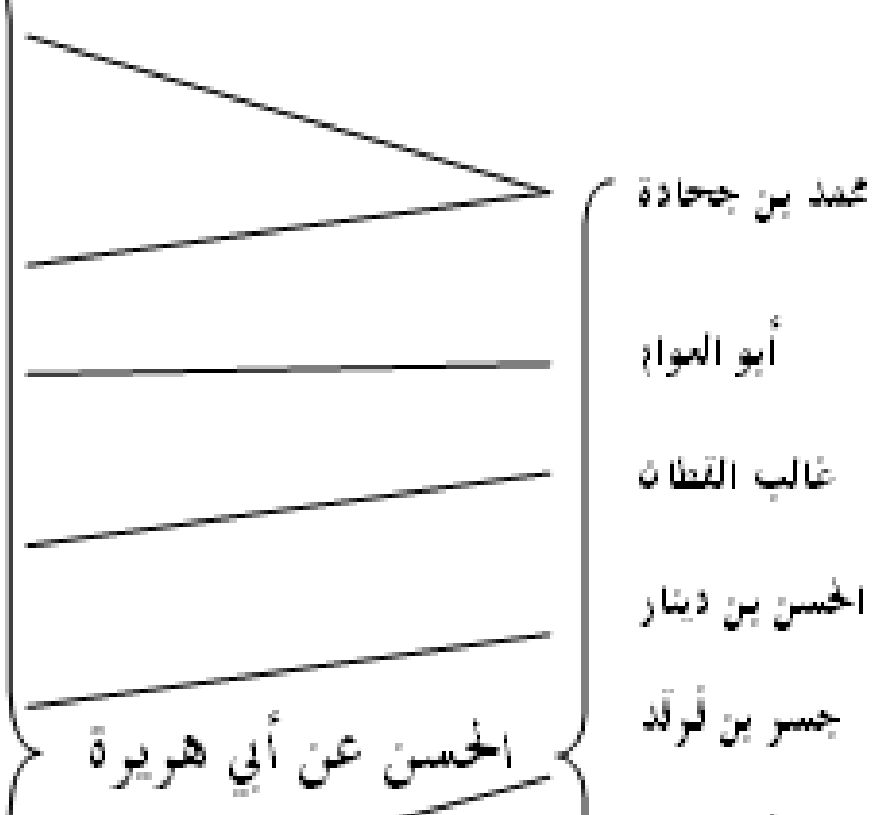

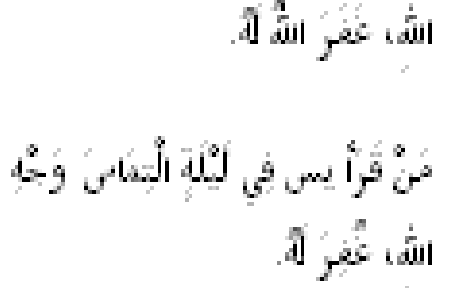

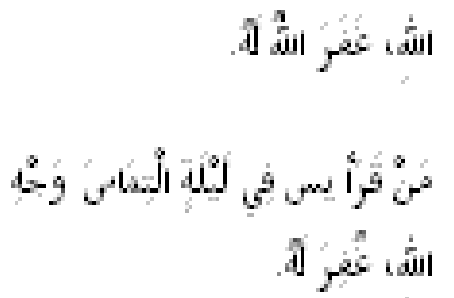

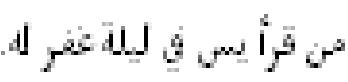

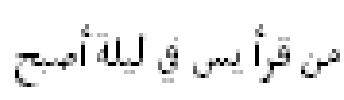

tin. d d b is

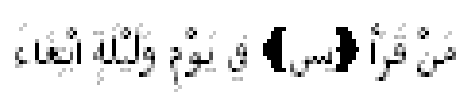

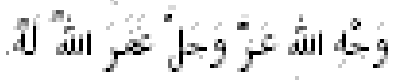

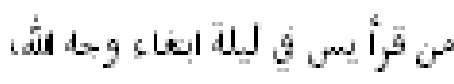

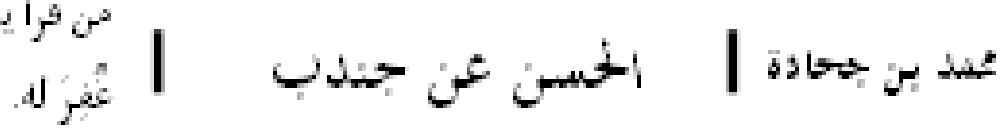

$$
\begin{aligned}
& \text { | } \\
& 4 y+1
\end{aligned}
$$

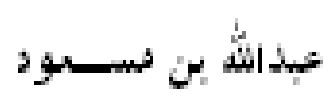

با

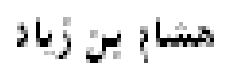

أy

ing

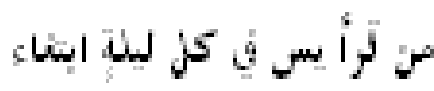

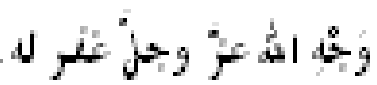

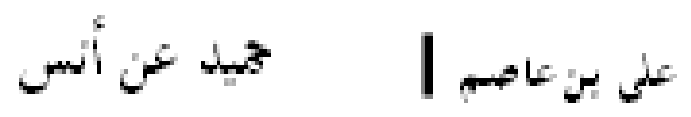


If it's seen from the entire sanad and matan hadith mentioned before, there have been differences in pronunciation matan hadith. The difference depends on the length of the short editorial hadith. The difference in pronunciation is certainly related to personal qualities (kesiqahan) each narrator. In the text of hadith assessed that matters is Syuja' and al-Hasan. For the time being the difference or the imposition of "revision" Hadith that are in the "hands" of both. However, Syuja' is still disputed in terms of dabit, as mentioned earlier.

Therefore, the attention was to al-Hasan himself. Authors cannot get the material of confirmation of al-Hasan narration with others. Because based on reading resources, there is no single history that independently can be justified. The analysis can be done in this section; changes of pronunciations are the responsibility of al-Hasan. Because, it is only him who received negative criticism and clearly narrated literal meaning. This is in accordance with the opinion of al-A'masy, that al-Hasan is constantly issuing statements filled with wisdom. Ja'far bin Muhammad bin 'Ali bin al-Husayn said that his statements are similar to the statements of the Prophet's wisdom, and its superiority in terms of fluency and balaghah. Ibn Sirin also said that al-Hasan after hearing hadith, he is then renew the pronunciation and words convey a lesson. ${ }^{50}$ For the revised forms are used can be seen in the scheme of matan hadith which have been laid.

\section{b. Substantial criticism}

To determine the content of the substance or content of hadith about reading surah Yasin in the night, can be analyzed from three sides reference relevance matan, they are: Relevance interpretative restricted al-Qur'an, recommendation relevance

${ }^{50}$ see al-Shafdî, al-Wâfî, juz III, 122; 'Uwaydah, al-Hasan, 26, 58 . of other true narration and relevance stylish with prophetic expressions.

(1) Interpretative relevance of al-Qur'an

Based on search through various syarahan hadith above, the information obtained is simply related to the meaning of the sentence: Ibtigha , wajhillah. ${ }^{51}$ This sentence is defined as: Looking for or expect to be able to look at "face" of God in the hereafter. So it's not meaningful expect to be spared from punishment of hell, or find a fortune to go to heaven. This was disclosed alManawy in Fay al-Qadir. ${ }^{52}$

But according to the author, to find the meaning of the content that can be analyzed in terms of relevance of al-Qur'an is the phrase that indicates: Man qara'a Yasin fi lailah (anyone who reads (surah) Yasin at night). It can be understood from this statement that the use of time to read the al-Qur'an (specially surah yasin) at night is highly recommended. This is understood from the end of hadith, which reward merit, in the form of forgiveness of sins (especially at night).

If it is seen from some verses of al-Qur'an that talk about the utilization of the night, it appears that there is a type of worship that is particularly recommended for Muslims. Example can be seen in the following verses: and keep vigil for a part of the night as a supererogatory (devotion), it may be that your Lord will will raise you to a praiseworthy station (QS.al-Isra' (17): 79). So be patient over what they say and exalt [Allah] with praise of your Lord before the rising of the sun and before its setting; and during

\footnotetext{
${ }^{51}$ The writer could not find the historical background of this Hadith in literature asbâb al-wurûd, such al-Bayân wa al-Ta 'rîf fî Asbâb al-Wurûd al-Hadîts al-Syarîf work of Ibn Hamzah al-Husaynî al-Hanafî al-Dimasqî and alLam 'u fì Asbâb Wurûd al-Hadîts work Jalâl al-Dîn alSuyûmî. This is presumably result is not reviewed its historical relevance aspects to the analysis of the content, as is commonly done in other.

${ }^{52}$ see 'Abd al-Rawf al-Manâwî, Fay al-Qadîr: Syarh alJâmi 'al-Shagîr, juz VI, edt. II (Beirut: Dâr al-Ma'rifah, 1972), 200.
} 
periods of the night [exalt Him] and at the ends of the day, that you may be satisfied (QS. Thaha (20): 130). Exalt [Him] night and day [and] do not slacken (QS. al-Anbiya '(21): 20). Is one who is devoutly obedient during periods of the night, prostrating and standing [in prayer], fearing the Hereafter and hoping for the mercy of his Lord (QS. az-Zumar (39): 9). And [in part] of the night exalt Him and after prostration (QS. Qaf (50): 40). And in a part of the night exalt Him and after [the setting of] the stars (QS. al-Tur (52): 49). Arise [to pray] the night, except for a little (QS.al-Muzammil (73): 2).

Based on some of verses above, it is clear that there are two types of worship that is highly recommended to do at night, they perform night prayer (qiyam al-layl) and zikir with tasbih. This is certainly different from the advice contained in analyzed hadith in this paper.

(2) Recommendation Relevance of other narration

In this part, the content of hadith about reading surah yasin at night will be linked with true hadith (read: Shahihayn book). Content is materials ratio remained which is as in the previous relevance, it is drawn from the expression: Man qara'a Yasin fi laylah (anyone who reads (surah yasin at night), or in other word is a suggestion in utilizing the time to read al-Qur'an (surah yasin especially) at night.

The following is hadith in question, as a comparison toward content of hadith that were examined:

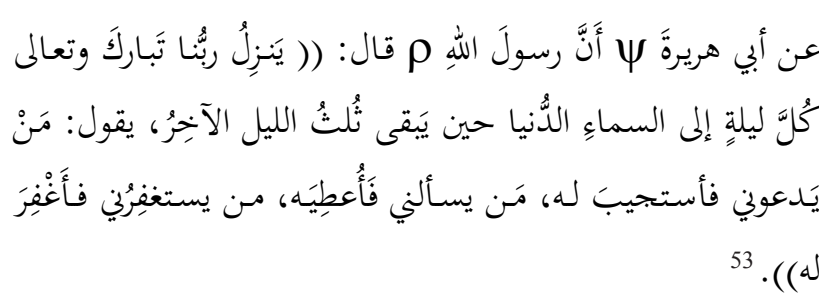

\footnotetext{
${ }^{53}$ Abû 'Abdillâh Muhammad bin Ismâ'îl al-Bukhârî, Shahîh al-Bukhârî, edt. I (Damaskus: Dâr Ibn Katsîr, 2002), 277; Abû al-Husayn Muslim bin al-Hajjâj al-Qusyayrî alNaisâbûrî, Shahîh Muslim, jilid I, edt. I (al-Mamlakah al-
}

From Abu Hurayrah ra., that the Messenger of Allah. He said: "(overflow mercy) our God (Allah) tabaraka wa ta 'ala every night down to the lowest heaven during the night in the third end, God says," Anyone who pray to Me, surely I grant for (prayer) it, anyone who asks (something) to me, surely I gave him, anyone who beg for forgiveness to me, surely I forgive him." ${ }^{54}$

Hadith muttafaq 'alayh above, it give further strengthening argument that the optimization of worship at night, it refers to the worship in the form of prayers (other than the beads according to the preceding verses). Silence of the night could be a situation that helps the onset of absorption in worship. With the solemnity, the opportunities for a servant to be able to communicate with his Lord without any limit, as well as ask any appeal to him, including a request for forgiveness in the evening, or at night before.

(3) Stylish Relevance with prophetic expressions If we refer to the benchmarks formulated by Shalah al-Din al-Adlabi, then spontaneously may hadith - about reading surah yasin at nightthis is very relevant to the style his utterance as a prophetic expression. Because it is not found phrases that indicate randomness diction of words, or show a low significance, nor the discovery of the use of scientific terms are known by scholars of khalaf.

This is understandable because the speakers have expertise in the field of language, literature and science of religion, al-Hasan (al-Basri). As

\footnotetext{
'Arabiyah al-Su'ûdiyyah: Dâr al-Mughnî li al-Nasyr wa al-Tauzî‘, 1998), 342; Ibn al-Sinnî, Kitâb 'Amal al-Yawm wa al-Laylah, 179.

${ }^{54}$ Most translation refers to the thought given by Ismail Syuhudi, see Syuhudi Ismail, Hadis Nabi yang Tekstual dan Kontekstual: Telaah Ma'ani al-Hadith tentang Ajaran Islam yang Universal, Temporal, dan Lokal, edt. II (Jakarta: Bulan Bintang, 2009), 20.

${ }^{55}$ Al-Albânî, al-Rau, 73, 74.
} 
discussed earlier, that al-Hasan (al-Basri) narrated hadith by literal meaning, so the possibility to use proper diction of the narrator can not be denied.

\section{Implications of Juridical Hadith recite Surah Yasin at Night}

Tadlis hadith that have been infected, according to scholarly and experts ushul not accepted (la yuqbal) unless the culprit (mudallis) using sama ' $i$ pronunciation. In contrast, according to Ibn Hazm who think that hadith this is not accepted unanimously. ${ }^{55}$

If the view of the condition of sanad and pronunciations are used in genealogy sanad, it will be found some of the narrator uses the pronunciation 'an 'anah. It is as 'an' 'anah carried out by al-Hasan and Muhammad bin Juhadah. But that is a problem is' an'anah al-Hasan. Besides being caused al-Hasan did not use sama' $i$ pronunciation, he was also considered doing tadlis. These conditions resulted in unbroken sanad lines between al-Hasan and narrators at the level above it (in this case Abu Hurayrah). This unsustainable is an impossibility to say that hadith are studied is true. Therefore, based on the foregoing, hadith of reading surah Yasin at night is punished mardud (rejected) its evidence.

\section{Conclusion}

Hadith about reading surah Yasin at night can only be found in one book belonging to alkutub al-tis ' $a$ h (nine books of hadith standard), it is at Sunan al-Darimi. Moreover, it can also be found in other books such as: Shahih Ibn Hibban, Mawarid al- "am 'an karya al-Haytsami, al-Jami " li Syu' 'ab al-Iman work of al-Bayhaqi, al-Mu 'jam al-Awsam by al-labrani, Musnad Abi Dawud allayalisi, Musnad Abi Ya 'la al-Mawshiiy, Kitab 'Amal al-Yawm wa al-Laylah work of Ibn alSinni, al-Kamil fi u'afa' al-Rijal by al-Jurjani, Kitab al-Maw

$u$ 'at work of Ibn al-Jawzi, Juz' Hanbal work of Ibn al-Sammak, al-Mu 'jam karya Ibn Muqri', Hilyah al-Awliya' work al-Ashfahani, and others, analysis on hadith of reading surah Yasin at night from al-Darimi narration contain sanad disjuncture, that is between al-Hasan and Abu Hurayrah. These indications came from suspect tadlis suspect alleged to al-Hasan. This discontinuity evidence is also reinforced by the comments of hadith critical, coupled with the argument in terms of geographical location as noted. In addition there is a narrator problematic as Abu Hurayrah and Syuja' bin al-Walid bin Qays al-Sakuni. From the side of matan, it seem rather irrelevant to the advice of al-Qur'an and other true hadith, although there is relevance with stylish prophetic language. Therefore, hadith of reading the Surah Yasin at night have weak status and cannot be used as evidence in charity.

The results of this study are not intended to prevent the Muslims to read or do wirid Surah Yasin at night. For reading surah/verses from alQur'an (Surah yasin included) and be continuous (dawam) in a highly recommended acts of worship in Islam. However, through the results of this study, the authors would like to invite at the same time hope that Muslims do not assume that specializes in reading Surah particular at night (read: surah Yasin) is a guidance directly from the Prophet. Let alone think by reading this Surah, it would forgiveness (maghfirah) God. But this is simply an act of worship belonging to any good deeds (al-shalihat).

\section{Bibliography}

al-Adlabi, Salah al-Din bin Ahmad. Manhaj Naqd al-Matn 'inda 'Ulama' al-Hadits. Cet. III. Beirut: Dar al-Afaq al-Jadidah, 1983.

al-Albani, Muhammad Nashir al-Din. al-Raud alDani fi al-Fawa'id al-Haditsiyyah. Cet. I; Yordan: al-Maktabah al-Islamiyyah, $1422 \mathrm{H}$.
- - a if al-Jami ' al-Shagir wa Ziyadatuhu: Al-Fath al-Kabir. Cet. III; Beirut: Maktab al-Islami, 1988.


al-Ashfahani, Abu Na'im Ahmad bin Abdillah. Hilyah al-Auliya' wa labaqat al-Ashfiya'. Juz II. Cet. I. Beirut: Dar al-Kutub al'Ilmiyyah, 1988.

al-'Asqalani, Ahmad bin 'Ali bin Hajar. alMamalib al-'Aliyah bi Zawa'id alMasanid al-Tsamaniyah. Juz XV. Cet. I. t.tp.: Dar al-'Ashimah, 1998.

—_- Tahdzib al-Tahdzib. Juz IV. t.tp:

Mu'assasah al-Risalah, t.th.

-. Taqrib al-Tahdzib. Cet. III. Damaskus: Dar al-Qalam, 1991.

al-Basya, 'Abd al-Rahman Ra'fat. Shuwar min Hayah al-Tabi in. t.tp: Dar al-Adab alIslami, 1997.

al-Bayhaqi, Abu Bakr Ahmad bin al-Husayn. alJami“ li Syu'ab al-Iman. Juz IV. Cet. I. Riyad: Maktabah al-Rusyd, 2003.

al-Bakjari, 'Ala' al-Din Muglami Ibn Qalij bin 'Abdillah. Ikmal Tahdzib al-Kamal fi Asma' al-Rijal. Juz V. Cet. I. Kairo: alFaruq al-Haditsiyyah li al-laba'ah wa alNasyr, 2001.

al-Bandari, 'Abd al-Gaffar Sulayman dan Sayyid Kisruway Hasan. Mausu 'ah Rijal Kutub al-Tis 'ah. Juz I. Cet. I. Beirut: Dar alKutub al-'Ilmiyyah, 1993.

al-Bushyri, Syihab al-Din Ahmad bin Abi Bakr bin Isma'il. Ithaf al-Khirah al-Maharah bi Zawa'id al-Masanid al- 'Asyrah. Juz VI. Cet. I. Riyad: Dar al-Waman li al-Nasyr, 1999.

al-Bukhari, Abu 'Abdillah Muhammad bin Isma'il. Shahih al-Bukhari. Cet. I. Damaskus: Dar Ibn Katsir, 2002.

al-Busti, Abu Hatim Muhammad bin Hibban bin Ahmad al-Tamimi. Kitab al-Tsiqat. Juz VI. Cet. I. Hyderabad: Mamba'ah Majlis Da'irah al-Ma'arifal-'Utsmaniyyah, 1978. al-Dinauri, Abu Bakr Ahmad bin Muhammad. dikenal Ibn al-Sinny. Kitab 'Amal al-Yawm wa al-Laylah. Cet. I. Damaskus: Maktabah Dar al-Bayan, 1987.

al-Dzahabi, Syams al-Din Muhammad bin Ahmad. Mizan al-I'tidal fi Naqd al-Rijal. Juz II. Cet. I. Beirut: Dar al-Kutub al'Ilmiyyah, 1995.

-. Siyar A 'lam al-Nubala'. Juz II. Cet. II. Beirut: Mu'assasah al-Risalah, 1982.

- Tajrid Asma'al-Shahabah. Juz I. Beirut: Dar al-Ma'rifah, t.th.

—. Tadzhib Tahdzib al-Kamal fi Asma'alRijal. Juz VIII. Cet. I. Kairo: al-Faruq alHaditsiyyah li al-laba'ah wa al-Nasyr, 2004.

al-Farisi, al-Amir 'Ala' al-Din 'Ali bin Balban. Shahih Ibn Hibban bi Tartib Ibn Balban. Juz VI. Cet. II. Beirut: Mu'assasah alRisalah, 1993.

al-Hadi, 'Abd al-Mahdi bin 'Abd al-Qadir bin 'Abd. 'Ilm al-Jarh wa al-Ta'dil: Qawa iduhu wa A'immatuhu. Cet. II. t.tp: t.p, 1998.

al-Haytsami, Nur al-Din 'Ali bin Abi Bakr. Mawarid al-'am 'an ila Zawa'id Ibn Hibban. Juz II. Cet. I. Damaskus: Dar alTsaqafah al-'Arabiyah, 1990.

al-Husayni, Abu al-Mahasin Muhammad bin 'Ali al-'Alawi. Kitab al-Tadzkirah li Ma'rifah Rijal al-Kutub al-'Asyrah. Juz I. Kairo: Maktabah al-Khaniji, t.th.

Ibn 'Ali al-Maqdisi, Abu al-Fadl Muhammad bin lahir. Kitab li Jam' bayna Kitabay Abi Nashr al-Kalabadzi wa Abi Bakr alAsfihani. Juz II. Cet. II. Beirut: Dar alKutub al-'Ilmiyyah, $1405 \mathrm{H}$.

Ibn al-'Ajami, Sabm. Al-Tabyin li Asma' alMudallisin. Beirut: Dar al-Kutub al'Ilmiyah, 1986.

Ibn al-Jawzi, Abu al-Farj 'Abd al-Rahman bin 'Ali 
bin Muhammad bin Ja'far. Kitab alMawdu'at min al-Ahadits al-Marfu' 'at. Juz I. Cet. I. Riyad: Adwa’ al-Salaf, 1997.

Ibn Katsir, 'Imad al-Din Abu al-Fida' Isma'il. Tafsir al-Qur'an al- 'A “im. Juz XI. Cet. I. Jezah: Mu'assasah Qurmubah, 2000.

Ibn Muqri’. al-Mu 'jam. Cet. I. Riyad: Maktabah al-Rusyd, 1998.

Ibn Qani'. Abu al-Husayn 'Abd al-Baqi. Mu 'jam al-Shahabah. Juz II. t.tp.: Maktabah alGuraba' al-Atsariyyah, t.th.

Ibn al-Sammak. Juz' Hanbal: al-Tasi' min Fawa'id Ibn al-Sammak. ditahqiq oleh Hisyam bin Muhammad. Cet. I. Riyad: Maktabah al-Rusyd, 1998.

al-'Iraqi, Abu al-Fadl Zayn al-Din 'Abd al-Rahim bin al-Husayn. Fath al-Mughits by Syarh Alfiyah al-Hadits. Beirut: Dar al-Fikr, 1995.

-. al-Mughni 'an Haml al-Asfarfial-Asfar fi Takhrij ma fi al-Ihya'min al-Akhbar. Juz I. Cet. I. Riyad: Maktabah labariyah, 1995.

Jasim, iya' Muhammad Mahmud. Dawr alShahabah fi Hif" al-Sunnah alNabawiyah wa Nasyriha. Cet. I. Beirut: Dar al-Kutub al-'Ilmiyyah, 2007.

al-Jurjani, Abu Ahmad 'Abdullah bin 'Udi. alKamil fii u'afa' al-Rijal. juz VI. Beirut: Dar al-Kutub al-'Ilmiyah, t.th.

al-Khalaf, 'Awwad. Riwayat al-Mudallisin fi Shahih al-Bukhari: Jam 'uha Takhrijuha al-Kalam 'alaiha. t.tp: Dar al-Basya'ir alIslamiyyah, t.th.

al-Khamis, 'Abd al-Rahman bin Ibrahim. Mu 'jam 'Ulum al-Hadits al-Nabawi. t.tp: Dar Ibn Hazm, t.th.

al-Lahham, Ahmad Isma'il Syakukani dan Shalih 'Utsman. Mu'jam Asami al-Ruwat alladzina tarajama lahum al-'Allamah Muhammad Nashir al-Din al-Albani
Jarhan wa Ta'dilan. Juz II. Cet. I. Beirut: Dar Ibn Hazm, 2000.

al-Manawi, 'Abd al-Rawf. Faid al-Qadir: Syarh al-Jami ' al-Shaghir. Juz VI. Cet. II. Beirut: Dar al-Ma'rifah, 1972.

al-Mizzi, Jamal al-Din Abu al-Hajjaj Yusuf. Tahdzib al-Kamal fi Asma' al-Rijal. Juz VI. Cet. I. Beirut: Mu'assasah al-Risalah, 1983.

al-Naysaburi, Abu al-Husayn Muslim bin alHajjaj al-Qusyayri. Shahih Muslim. Jilid I. Cet. I. al-Mamlakah al-'Arabiyyah alSu'udiyyah: Dar al-Mughni li al-Nasyr wa al-Tauzi', 1998.

al-Nasa'i, Abu 'Abd al-Rahman Ahmad bin Syu'aib bin 'Ali. al-Mujtaba min al-Sunan al-Masyhur bi al-Sunan al-Nasa'i. Riyad: Bayt al-Afkar al-Dawliyah, t.th.

-. Tasmiyah Masayikh wa Dzikr alMudallisin. Cet. I. Mekah al-Mukarramah: Dar 'Alam al-Fawa'id, $1423 \mathrm{H}$.

al-Samarqandi, 'Abdullah bin 'Abd al-Rahman al-Darimi, Sunan al-Darimi. Juz II. Karachi: Qadimi Kutub Khanah, t.th.

al-Shafdi, Shalah al-Din Khalil bin Ibik. al-Wafi bi al-Wafayat. Juz XII. Cet. I. Beirut: Dar Ihya' al-Turats al-'Arabi, 2000.

al-Shiddiqi, Sajid al-Rahman. al-Mu 'jam alHadits fi 'Ulum al-Hadits. Beirut: Dar alKutub al-'Ilmiyyah, 2005.

Al-Syahrazuri, Abu 'Amru 'Utsman bin 'Abd alRahman. Ma 'rifah Anwa' 'Ilm al-Hadits. Cet. I. Beirut: Dar al-Kutub al-'Ilmiyyah, 2002.

Syuhudi Ismail. Hadis Nabi yang Tekstual dan Kontekstual: Telaah Ma'ani al-Hadits tentang Ajaran Islam yang Universal, Temporal, dan Lokal. Cet. II. Jakarta: Bulan Bintang, 2009. -. Metodologi Penelitian Hadis Nabi. Cet. 
II. Jakarta: Bulan Bintang, 2007.

al-Tabrani, Abu al-Qasim Sulayman bin Ahmad. al-Mu 'jam al-Awsam. Juz IV. Kairo: Dar al-Haramayn, 1995.

al-Tahhan, Mahmud. Ushul al-Takhrij wa Dirasah al-Asanid. Cet. III. Riyad: Maktabah al-Ma'arif li al-Nasyr wa alTauzi`, 1996.

al-Tamimi, Ahmad bin 'Ali bin al-Mutsanna. Musnad Abi Ya la al-Mawshili. Juz XI. Cet. II. Damaskus: Dar al-Ma'mun li Turats, 1989.
'Uwaydah, Kamil Muhammad Muhammad. alHasan al-Bashri: Imam Ahl al-Bashrah. Cet. I. Beirut: Dar al-Kutub al-'Ilmiyyah, 1995.

Wa'iz, Muhib al-Din 'Abd al-Subhan. Fad a'il Surah Yasin fi Mizan al-Naqd. Beirut: Mu'assasah al-Rayyan, t.th.

Zulfahmi Alwi. "Metodologi Takhrij al-Hadits: Memantapkan Keberadaan Ilmu Takhrij al-Hadits sebagai Disiplin Ilmu". Jurnal Tahdis 1, no.1 (2010): 7-26. 